\title{
The Importance of Teaching English through Armenian Culture
}

\author{
Meline Ghonyan \\ American University of Armenia
}

\begin{abstract}
Culture and art have always been indispensable parts of language teaching. Cultural texts and various cultural topics have been included in language books and textbooks. However, textbook developers and English teachers give priority to teaching the culture of the target language rather than that of native learners.

In the current paper we would like to state that it is beneficial to teach English through local culture materials as they increase the cognitive, communicative and social understanding of the learners.

Having based on our teaching experience, we can claim that specific topics like Armenian music, dances, customs and traditions, Armenian artists and their art works, the cities and architecture, filming and theatre, holidays and festivals and other culture-related topics are of great interest to Armenian learners of English. These topics are, to some extent, familiar to them, so they enhance the learners' English communicative skills. Moreover, the learners obtain a full comprehension of Armenian culture and develop certain skills to present it to others.
\end{abstract}

Key words: local culture, target culture, cultural materials, culture-related topics .

\section{Introduction}

Armenian learners are rarely exposed to Armenian culture; the only topics that are related to Armenia are Armenian History, Religion and Geography.

Meanwhile, Armenian culture and art are considered to be the most interesting and valuable items of the Armenian heritage. Our ancestors left us a very rich culture and it is important to use Armenian cultural materials during English classes to highlight the national identity of the learners. Therefore, as a teacher, I felt responsible to create a course which would introduce the local culture and art in the English language. Being an international language, English will provide a great opportunity for the Armenian learners to present their culture to foreigners 
who will become more interested in the country of Armenia and its culture. Thus, we have carried out a project on the attempt to teach English through Armenian culture. The purpose of this project is to address three functions: cognitive, communicative, and social. The cognitive function implies that the learners will get to know the Armenian culture and art, specifically the topics that are not included in public school textbooks, which are Armenian music, dances, traditions, artists and their art works, cities, filming and theatre, fashion, and many others.

Communication will become easier when learners have an idea what exactly they are talking about, thus they will become more confident first to talk to each other and then discuss their local culture with people of other nationalities.

The third function of the course is to empower the learners with knowledge about their own culture in order to share this knowledge with representatives of other nationalities and, eventually contribute recognition of Armenian culture internationally.

\section{Definition of Culture}

In recognition of the explanation of culture, Choudhury defines it as the characteristics of a particular group of people, defined by everything from language, religion, cuisine, social habits, music and arts" (Choudhury 2014).

As culture is defined in many different ways, there should be a precise understanding of what we think is acceptable for this project. As Kirkebæk \& Jensen (2013) explain it is important for the teacher whether the culture is an unchanging value system or treatment that groups of people have in common, whether the culture is a system which is always changing and typical of individuals, and shared during social interaction.

Through the choice and understanding of the concept of culture teachers may select methods and approaches for teaching it in a language classroom. For this project the most appropriate definition of culture is the one given by Peck (2015) which defines it as an accepted behavior shared by a group of people.

\section{The Relationship between Language and Culture}

Language is the means that people socialize with others, and when it becomes a tool for communication between people, it starts to be related with culture. When people talk and easily understand each other, when they have topics in common, this is because they share the same knowledge about their surroundings, that is, the 
culture of the country and culture in general, as claims "language expresses cultural reality" (Kramsch 2010).

By using language, people express attitudes, experiences and, moreover, gain experience. When talking on the phone, speaking face to face, or performing other activities with the help of language, adding gestures and mimics to it, people get to know each other better. They start using vocabulary, facial expressions, style and accent that are common for each other, they define themselves and others with the verbal and non-verbal aspects that are common for a group of people, so as Kramsch mentions " language embodies cultural reality" (ibid:3).

Finally, as Kramsch states in her book, language is considered to be a system of signs. Language is also a way of identifying people, their social and cultural status and rank, therefore "language symbolizes cultural reality" (ibid:3).

\section{Why Teach Local Culture?}

Culture is the phenomenon that is closely related to people, including the languages they speak, the lifestyle they have and the way of interaction they share. In the process of learning culture, learners first of all study their families, friends, their surrounding areas and learn on them, they have natural examples and their own experiences in front of them (Wagler 2004).

Teaching local culture is also important for the learners' individual development and the feeling of national identity. In the process of learning, the local culture students study their families, the actions of their ancestors, go back to their past, observe their present, and, most importantly, imagine their future. Learners better know who they are and walk forward with a deep knowledge about their own history (Wagler 2004).

It is very important to feel free while expressing ideas and discussing topics when starting to learn a language. The inclusion of local culture materials in the teaching curriculum gives learners the opportunity of being familiar with topics which they are exposed to in their daily life (Mahmoud 2015).

Moreover, learners, especially the ones in lower proficiency levels, may face difficulties while learning a new language and a new culture: the culture of the target language. They may feel a huge load and may be discouraged to continue studying. It is truly important to include the target culture while learning the language, because without it the learners, even though they will learn the language, will not be able to act in real life situations. 
As Mahmoud states "the use of local culture in the classroom environment decreases the possibility of assimilation and alienation" (Mahmoud 2015:70). Besides, learning the local culture helps to be closer and understand concepts in other cultures.

Thus, as the main purpose of learning a language is gaining the ability to communicate, the learners should also learn their own culture to be able to present it to other people.

\section{Ways of Teaching Culture}

As Clarke, et. al, (2002) state in their book, to teach culture effectively in the classroom the teacher should provide meaningful materials and why not, even visits to museums and galleries, because while teaching it is very important to see the real artifacts or other objects that are presented in the classroom, it is considered a nice way of teaching authentically. Only visiting cultural places is not enough to have an effective input for the learners, the teacher should also consult with experts who know everything the teacher and the learner need. In such courses there should be high level of knowledge and professionalism.

As stated in Clarke, et. al., the experience of visiting museums and libraries can be a very beneficial experience for students in their curricula, as they see a lot and feel a lot when seeing the real materials that they have been talking about and presenting so much during their classes. It is even better than having role-plays and other engaging activities. This way of teaching culture gives learning opportunities to the students who have weaker abilities, thus they are becoming more enthusiastic and involved in the teaching process.

After visiting museums and galleries, learners start to learn from simple objects. The museum exhibits make them realize the aesthetic value of such things in their surrounding area.

As Royani noted, for teaching culture in a language classroom it is very important to include texts about local culture. With the help of this learners are becoming more enthusiastic and motivated about the lesson. As they may be familiar with some of the patterns of their own culture, they are becoming more self-confident, feeling more important and needed. Including local culture texts in the course will be effective as the learners will get to know events, traditions and environment, thus increasing engagement in their lesson. Besides, when learners read texts related to their local culture, they understand better as they live in it. It 
eases the process of comprehension and then gives space for discussions (Royani 2013).

Local culture related texts can be appropriate for teaching L2 to any level of proficiency of learners. These kinds of materials are easy to obtain, even more; the materials can be created by the teachers themselves.

As Wagler mentions in his book, it is important to use media presentation during culture-language integrated lessons. Learners may present on slides, show some photos taken from local exhibitions or galleries. Learners may choose the cultural items and the audience of their presentations. This kind of presentations also encourage the feeling of community, when people work on a project which is familiar, they start feeling that they are one community (Wagler 2004).

\section{Teaching a Language through Local Art}

The value of art is highly appreciated and has an enormous power to impress people in a good sense. Art is also a valuable tool to foster learning and enrich the instruction of language teaching. Understanding the profound importance of Arts teachers are inclined to incorporate it in their teaching curricula (Ruiz 2010).

Integration of local art in language teaching helps to raise teaching to the high level of analysis in terms of all four skills: reading, writing, speaking and listening (Ruiz 2010).

Art comprises everything that is strongly related to human being and activities. Thus it allows the learners to challenge their background knowledge, activate their experiences to discuss art patterns, interpret them, explore and reflect on them. It also touches upon the spheres of communicating ideas and interaction between people. The inclusion of art in teaching languages also evokes the imagination and creativity of learners which helps them to better deepen the language skills (Ruiz 2010).

Art also gives a wide opportunity for the learners to activate their background knowledge and tap to concepts that they know, and which will serve a nice ground for developing the language.

As art can be visually shown and serves as a non-verbal type of communication, learners, even the ones who have a low proficiency level, can express their feelings and ideas, and even interact with others during discussions (Ruiz 2010).

Inclusion of Arts in teaching languages gives a huge chance for learners having different backgrounds and language knowledge to develop their creative thinking, problem solving skills, and help them critically analyze issues. Through art, 
learners gain confidence, they express their ideas, feel that their ideas are appreciated and, even more, they start appreciating the ideas of others (Ruiz 2010).

Every work of art can be included in the lesson. It is a nice way to gather all the learners around and start discussing, it is the place where learners are not ashamed to express their ideas, and in this case, they can speak, as art work is a visual material that provides interaction between classmates and the teacher (Ruiz 2010).

Narowski notes a hands-on tool which provides learners with space for showing experiences and learning from them, it gives an opportunity to think critically and have clear and beneficial outcomes in writing and speaking. She states that all the students liked it, as none of them was left out, everyone had a platform to express his thoughts and be heard, everyone could say something that was worth listening. This approach proved to be the key success of her course. Integrating art into a language learning course is especially effective for those who have hard times reading, who think that reading is not appropriate for them as a teaching technique. In this case art works come forward. Art works can be placed in front and serve as a material to speak, to communicate, even to learn language items and functions (Narowski 2015).

\section{Conclusion}

During the implementation of the project, the actual teaching and the literature review, we may come to the conclusion that it is really important and beneficial to teach local (Armenian) culture to Armenian students. Due to teaching local cultural materials in English, Armenian students become, first of all culturally aware; they also study different aspects of Armenian culture, the components of culture in general. Secondly, local cultural materials help them to express themselves more easily in English, they are more familiar with topics, and as it is claimed in literature, students speak more freely, and learn the language more easily when they are exposed to topics familiar to them. And finally, the local cultural materials give the opportunity to use interesting reading materials, diverse activities which make the language learning process more interesting and productive.

\section{References:}

1. Choudhury, R.U. (2014) The Role of Culture in Teaching and Learning of English as a Foreign Language. // Express International Journal of Multi- 
Disciplinary Research. Available at: <www.express-journal.com> [Accessed June 2016].

2. Clarke, A.; Dodd, J.; Hooper-Greenhill, E.; O’Riain, H.; Selfridge, L.; Swift, F. (2002) Learning through Culture. Leicester: RCMG Publishers.

3. Elmes, D. (2013) The Relationship between Language and Culture. / National Institute of Fitness and Sports in Kanoya International Exchange and Language Education Center. Available at: <http://www2.lib.nifs-k.ac.jp/HPBU/annals/ an46/46-11.pdf $>$ [Accessed June 2016].

4. Kirkebæk, M.J.; X.-Yun Du and Jensen, A.A. (2013) Teaching and Learning Culture, Negotiating the Context. Rotterdam: Sense Publishers.

5. Kramsch, C. (1998) Language and Culture. Oxford: OUP, pp. 3-5.

6. Lightfoot, A. (2003) Art in the Classroom. / British Council. Available at: $<$ https://www.teachingenglish.org.uk/article/art-classroom $>$ [Accessed May 2016].

7. Mahmoud, M. (2015) Culture and English Language Teaching in the Arab World. // Adult Learning.

8. Narowski, L. (2015) Using Art to Encourage Effective Speaking and Writing Skills with ESL Students. The Yale New Haven Teachers Institute, Available at: $<$ http://www.yale.edu/ynhti/curriculum/units/2009/1/09.01.08.x.html> [Accessed May 2016].

9. Peck, D. (2015) Teaching Culture: Beyond Language. / The Yale-New Haven Teachers Institute. Available at: <http://www.yale.edu/ynhti/curriculum/units/ 1984/3/84.03.06.x.html> [Accessed June 2016].

10. Royani, M. (2012) The Use of Local Culture Texts for Enthusiastic English Reading Teaching. / The International Journal of Social Sciences, Vol. 7, N.1.

11. Ruiz, J.P. (2010) Art as a Tool for Teachers of English Language Learners. I The New York State Education Department Office of Bilingual Education and Foreign Languages Studies. The University of the State of New York.

12. Wagler, M. (2004) Teaching Local Culture. / Madison Children's Museum. Madison.

13. Wardhaugh, R. (2006) An Introduction to Sociolinguistics. $5^{\text {th }}$ edition, Blackwell Publishing, pp. 1-10. Available at: <http://home.lu.lv/ pva/Sociolingvistika/1006648_82038_wardhaugh_r_an_introduction_to_sociolinguistics. pdf $>$ [Accessed April 2016]. 


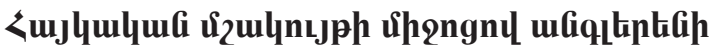 nıunıgưufi luplenpnıpjnıtip}

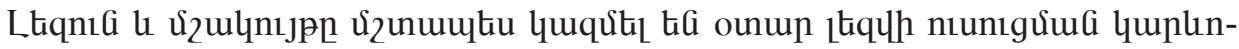

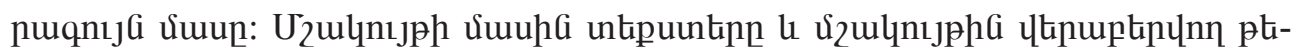

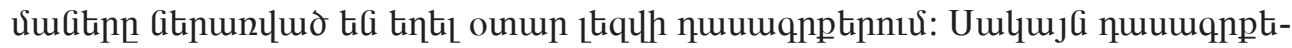

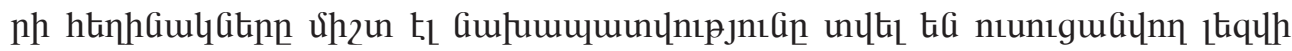

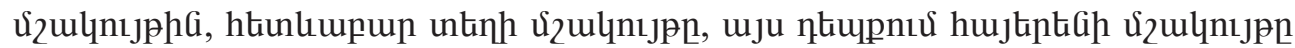

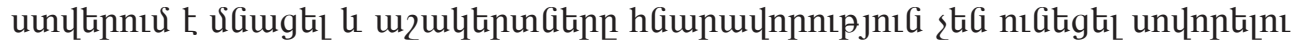

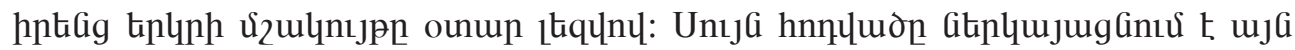

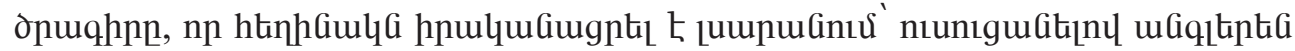

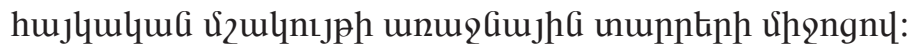

